\title{
Wildlife and Hunting As Alternative Farm Enterprises ${ }^{1}$
}

William M. Giuliano and Kristin C. Thomas ${ }^{2}$

Wildlife enhances our quality of life and is an integral part of the landscape. In addition, wildlife can be managed to provide revenue as part of alternative farm enterprises. The key to maintaining healthy wildlife populations necessary in such alternative enterprises is providing quality habitat through proper management (Figure 1).

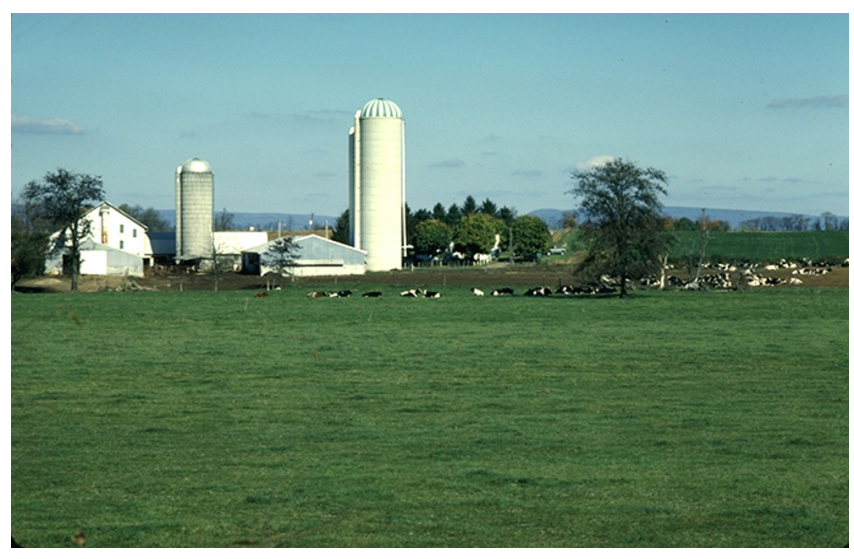

Figure 1. Proper habitat management on farms and ranches can lead to significant income from wildlife enterprises. Credits: USDA/Photo by Jay Beavers.

Wildlife management and conservation involves applying ecological knowledge to animal populations and habitats in a way that balances the needs of the animals and people and can be integrated into most farm management programs. Traditional agricultural practices have often been blamed for declines in wildlife populations. While there is room to improve such practices, the fact is, farms and ranches provide much-needed habitat for numerous wildlife species-without which many species would be in trouble.

Managing wildlife on farms and ranches can provide landowners with both tangible and intangible benefits. Tangible benefits include improved wildlife-related recreation and income. Activities include hunting opportunities, outdoor recreation involving wildlife, and production of wildlife and associated products (such as honey and milk). Revenue derived from these activities can provide significant primary or supplemental income, and funds to cover property taxes and management expenses. Intangible benefits from wildlife management include the excitement derived from observing wildlife, satisfaction from providing quality habitat for these species, and pride and recognition from making the property a better place.

Through the Small Farms/Alternative Enterprises: Managing the Farm for Wildlife and Hunting Web site, landowners can find more detailed

1. This document is WEC 197 and one of a series of the Department of Wildlife Ecology and Conservation, Florida Cooperative Extension Service, Institute of Food and Agricultural Sciences (IFAS), University of Florida. First published: July 2005. Please visit the EDIS Web site at http://edis.ifas.ufl.edu for more publications.

2. William M. Giuliano is an Assistant Professor and Wildlife Extension Specialist and Kristin C. Thomas is a Student; Department of Wildlife Ecology and Conservation, Cooperative Extension Service, Institute of Food and Agricultural Sciences, University of Florida, Gainesville, FL 32611.

The Institute of Food and Agricultural Sciences (IFAS) is an Equal Opportunity Institution authorized to provide research, educational information and other services only to individuals and institutions that function with non-discrimination with respect to race, creed, color, religion, age, disability, sex, sexual orientation, marital status, national origin, political opinions or affiliations. U.S. Department of Agriculture, Cooperative Extension Service, University of Florida, IFAS, Florida A. \& M. University Cooperative Extension Program, and Boards of County Commissioners Cooperating. Larry Arrington, Dean 
information on various wildlife species, how to manage wildlife and their habitat on the farm or ranch, ways of using wildlife as an alternative enterprise, and regulations regarding the use of wildlife in alternative enterprises.

Specific topics and types of information on the Web site include:

General Information-Information on the biology of various wildlife is needed to understand how a particular species can be used in an alternative enterprise.

Conservation-Wildlife conservation usually involves the practice of sensible and careful use of wildlife resources. Often, only slight enhancements are necessary to improve existing wildlife habitat and increase its value to a wildlife enterprise. However, if the habitat is severely degraded, a rehabilitative or replacement approach may be necessary. When considering a wildlife-related enterprise, an initial inventory and assessment of existing wildlife and habitat is a good place to start. Technical assistance is available through County, Wildlife, and Forestry Extension Services. Once goals for managing wildlife and habitat have been established, an agent can provide advice on cost share, easement, and assistance programs to help finance and plan the enterprise (Figure 2).

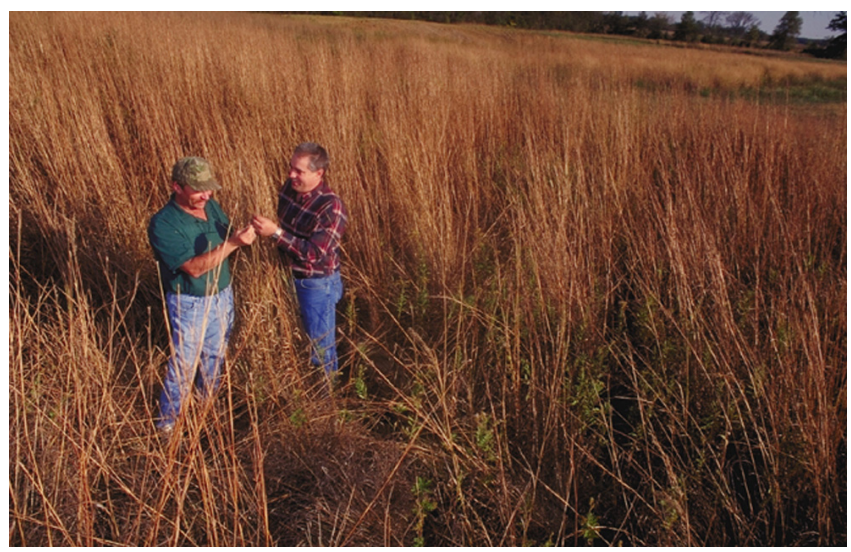

Figure 2. The Florida Cooperative Extension Service is one of many organizations providing assistance to landowners interested in using wildlife as an alternative enterprise. Credits: USDA/Photo by Ken Hammond.

Additional assistance on managing wildlife can be found through many wildlife-related organizations (for example: Florida Fish and Wildlife Conservation
Commission and USDA Natural Resource Conservation Service, Farm Service Agency, and Forest Service).

Agricultural Biodiversity - The Wildlife Society defines biodiversity as "the richness, abundance, and variability of plant and animal species and communities, and the ecological processes that link them with one another and with soil, air, and water." Many of our industrialized farming operations have emphasized monoculture approaches for intensive, high-yield production. Such operations have not taken full advantage of enhancing or incorporating more biodiversity. Although approximately 7,000 plant and dozens of animal species have been domesticated, cultivated, and collected for food by humans since agriculture began more than 12,000 years ago, $90 \%$ of our food today comes from only about 15 plant and 8 animal species.

Incorporating biodiversity on farms and ranches involves increasing the variety of genes, species, ecosystems, and ecological processes. Small farmers are taking the lead in incorporating more agricultural and wildlife biodiversity into their management practices through integrated pest management, whole farm planning, and multiple-use management. By finding ways of incorporating more biodiversity in their operation, many producers are realizing increased agricultural productivity, while at the same time reducing the financial liability of depending on a single crop or service for income. Agro-forestry, integrated farming, and sustainable agricultural system planning can all improve wildlife biodiversity and reduce financial liabilities associated with a single crop or service operation. This is accomplished by producing an increased variety of plants and animals that can be used for commerce and subsistence.

Agro/Ecotourism-Agro/ecotourism can be an important alternative enterprise for small farmers. Such an enterprise typically involves charging fees to access property for wildlife-related recreational activities such as hiking, canoeing, camping, and photography. It also includes the sale of items associated with these activities such as maps, food, canoe rentals, etc. 
Wildlife Farming and Ranching - Traditional views about wildlife farming and ranching often include images of large game species being raised for hunting. However, wildlife producers today are raising everything from buffalo to baitfish to butterflies. These animals may be native (found naturally in the area) or exotic (introduced from another area). Producers raise wildlife for a variety of products, services, and markets (Figure 3). Some of these include meat and other products (such as fur, milk, and eggs), and stock for zoos, hunting preserves, private collectors, research programs, and restocking of natural populations. As with any enterprise, a thorough evaluation of farming goals and an assessment of costs and potential markets for wildlife products should be conducted before starting a wildlife farming or ranching enterprise.

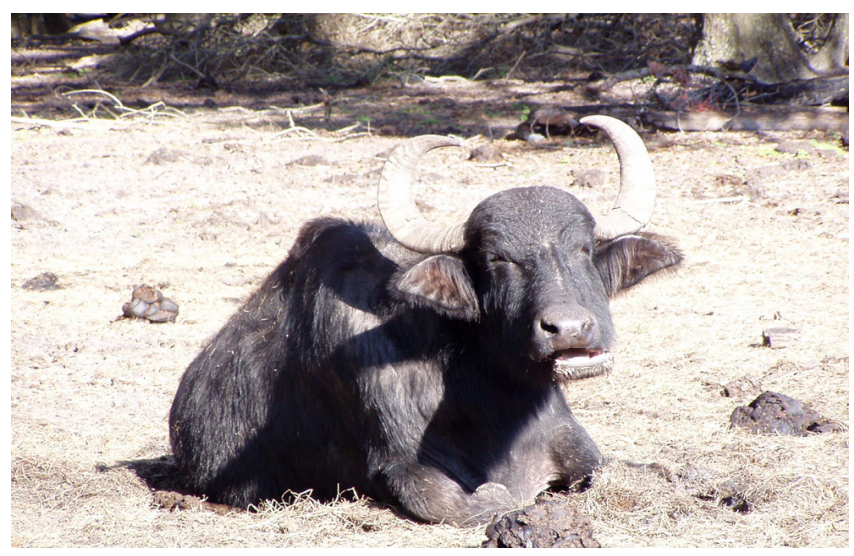

Figure 3. Producing wildlife, such as water buffalo, for meat, milk, and other products can be a lucrative alternative agricultural enterprise. Credits: Photo by W.M. Giuliano.

Hunting - The National Survey of Fishing, Hunting, and Wildlife-Associated Recreation reported that in Florida, individuals spend \$6.2 billion annually on fish and wildlife-associated recreation. More than 226,000 hunters contribute $\$ 394$ million to this total. Incorporating hunting as an alternative enterprise on a farm or ranch can generate income through the charging fees for access to property, harvesting of specific animals, and from the sale of items associated with these activities, such as food, lodging, and guide services.

About three-fourths of all hunter-days in the United States occur on private lands. Most hunters prefer to hunt on private instead of public lands; especially when they are locally convenient and accessible, and have high quality habitat and low hunter densities. In addition to actually "bagging" game, a large proportion of hunters also report relaxation, visual evidence of wildlife, companionship, and camaraderie as important components of a satisfying hunting experience-hunting can be a profitable, alternative enterprise.

There are many cost share and technical assistance programs available to help make habitat improvements for wildlife and enhance hunting opportunities. Hunting as an alternative farm enterprise typically involves either leasing hunter access to property or operating a hunting preserve.

Wildife Damage and Control-The USDA-APHIS Wildlife Services reports that more than half of all farmers and ranchers experience some kind of wildlife-related damage each year, with an estimated cost of more than $\$ 944$ million-such damage can negatively impact both traditional and wildlife-related enterprises. Concerns about wildlife damage to agricultural crops, livestock, other wildlife, habitat, or property should be directed to the USDA-APHIS Wildlife Services, Florida Fish and Wildlife Conservation Commission, or Florida Wildlife Extension.

Wildlife Regulations-Alternative enterprises involving wildlife are regulated by various agencies. A thorough review of pertinent regulations should be performed before entering into any such endeavor. In addition to international, federal, and state regulations, individual counties and cities may have special ordinances that should be checked before initiating any wildlife-related enterprise. Organizations such as the Florida Fish and Wildlife Conservation Commission are good sources of information on wildlife regulations.

\section{More detailed information on:}

Wildlife and Hunting as Alternative Farm Enterprises can be found at http://smallfarms.ifas.ufl.edu/WildlifeHunting

General Information on Alternative Farm Enterprises can be found at http://smallfarms.ifas.ufl.edu 